\title{
Voicing Feminist Resistance in Joumana Haddad's I Killed Scheherazade: Confessions of an Angry Arab Woman
}

\author{
Dr. Rasha Abdel Haliem Osman \\ Higher Technological Institute, Cairo, Egypt.
}

\begin{abstract}
Writing is a weapon women writers used throughout history to change reality, shatter stereotypes and give women voice. Arab women writers understand how writing is a political act that disrupts devaluating and oppressive systems. This paper sheds light on how literature can be used to resist. Joumana Haddad turns her anger into writing in order to resist reality, shatter stereotypes and enhance change. Haddad speaks for every Arab woman who feels like her and believes in similar choices and dogmas. Her novella I Killed Scheherazade: Confessions of an Angry Arab Woman is a book for Arab women that encompasses interrogation of Western assumptions about women of the Middle East, and demonstrates the necessity of internal criticism of culture. Haddad is aiming at collective Arab women empowerment. Haddad reflects on what it means to be an Arab woman and specifically an Arab woman writer in the current time, and shows a different picture of Arab women of that prevalent in the West. The aim of this paper is to shed light on contemporary Arab feminist resistance literature. The selected text is examined for the presence of voices of feminist resistance the writer employs to shatter stereotypes, enlighten the Western and Arab readers and give Arab women writers voice.
\end{abstract}

\section{Keywords}

Resistance, feminism, activism, Arab women writers, Western assumptions, stereotypes, oppression, marginality, voice and empowerment. 


\section{Voicing Feminist Resistance in Joumana Haddad's I Killed Scheherazade:}

\section{Confessions of an Angry Arab Woman}

$$
\text { التعبير عن المقاومة النسوية في رواية جمانة حداد “، قتلت شهرز اد : اعتر افات امر أة عربية }
$$

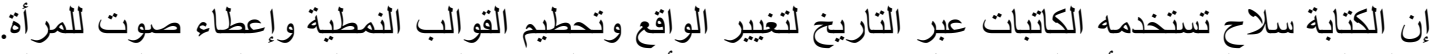

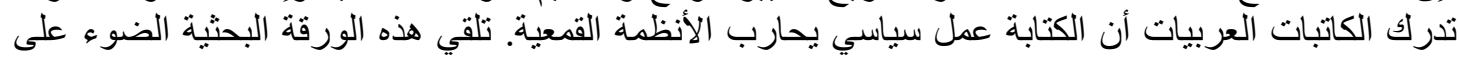

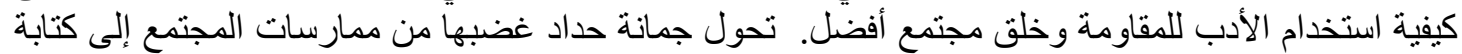

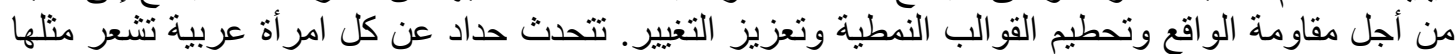

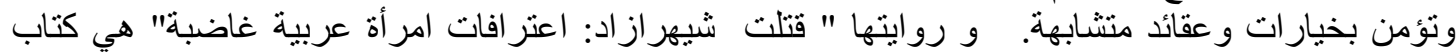

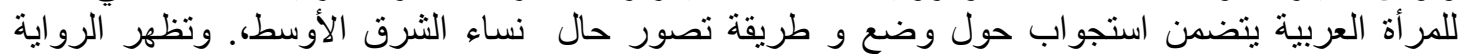

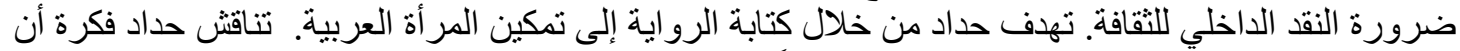

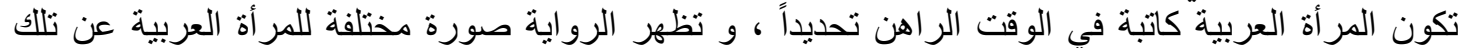

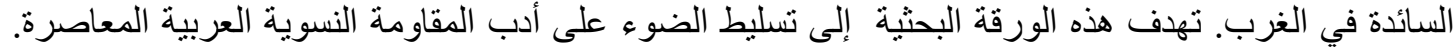

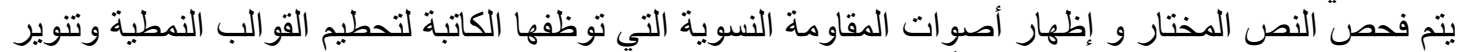

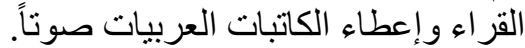
الكلمات الرئيسيه

المقاومة، النسوية، الكاتبات العربيات، الافتراضات الغربية، القوالب النمطية، القمع، الهامشية، الصوت

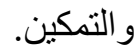




\section{Dr. Rasha Abdel Haliem Osman}

Resistance writers use writing as a weapon to communicate ideas to change reality. Throughout women writing history, writing was a weapon to change reality, shatter stereotypes, and lend women voice. Arab women writers understand how storytelling and narrative are powerful, and how language and writing are political. To many Arab women writers, writing is a form of activism as it actively disrupts systems that devalue and oppress women.

This paper sheds light on how literature can be used to resist. Joumana Haddad turns her anger into writing in order to resist reality and enhance change. Haddad speaks for every Arab woman who feels like her and believes in similar choices and dogmas. She writes a novella which is partly essay, partly prose, and partly poetry. It is a book that reflects on the state of Arab women, interrogates the Western assumptions about women of the Middle East, and demonstrates the necessity of internal criticism of culture. Joumana Haddad reflects on what it means to be an Arab woman and specifically the Arab woman writer in the current time, and shows a different picture of Arab women than that prevalent in the West. The book centers on Haddad's life and experiences as a writer, which differ from many average Arab women. The theme of the book is resistance via writing to change Arab women's reality. Haddad writes the novella in English though she is addressing both Western and Arab readers. In the novella, she is presenting her story, the story of an Arab woman writer who is resisting the statuesque via writing. Her choice of English language is a resistance technique. She eventually rewrites/translates the text into Arabic. Haddad aims at voicing resistance, shattering stereotypes, enhancing collective Arab women empowerment and giving Arab women writers' voice. ${ }^{1}$

Joumana Haddad is critically celebrated in the Arab world and in the West. Haddad is a Lebanese poet, translator, journalist, script writer, actress and women's rights activist. Arabian Business Magazine selected Haddad as one of the world's 100 most powerful Arab women for four consecutive years. She founded Jasad, a quarterly Arabic-language magazine. Haddad is widely acclaimed by critics for her literary productions including several poetry collections and two confessional autobiographical pieces, namely I Killed Scheherazade: Confessions of an Angry Arab Woman and Superman is an Arab. Her books have been translated to many languages and published worldwide. Haddad has written books in different languages, and has also published several works of translation, including an anthology of Lebanese modern poetry in Spanish (Ladkani 1). 
Women writers write to change reality. Resistance entails reinterpretation of women reality, hearing women voices and considering the dispossessed, subjugated, powerless and suppressed. Throughout $I$ Killed Scheherazade, Haddad insists on rethinking of the past, eliminating the traditional hegemonic biases, giving voice to the silenced, and presenting the obstructed identity of women. As Lila Abu-Lughod explains resistance entails communication towards a common goal (121). Haddad is communicating her ideas to both Western and Arab readers. This makes her write I Killed Scheherazade in English and eventually rewrites/translates the text into Arabic.

Western critics study Arab women writers as a group because of the prevailing themes in their writings. Critics who study contemporary Arab women understand that though Arab women writers have similar concerns, still cultural, social, and individual differences are found. Enlightened critics try to take care of these differences, but the governing aspect in criticism is generalization. Some critics still disregard the discrete subtle differences among Arab women and study Arab women and Arab women writers by general feminist literary theories. 2 Nonetheless, what connects feminist writers is the theme of voicing resistance.

Arab women writers use literature as a resistance tool. Literature is a tool that enhances feminist issues and portray women's reality. Nawal El Saadawi (2013) has drawn critics' attention to Arab women writers' role in enhancing Arab women feminist issues. In the Arab World, the relationship between women and literature is in continuous change, because of the continuous and evolving nature of women participation and experimentation in literature. The shift in this relationship is somehow affected by the changes that have marked the social and feminist movement in the Arab world. El Saadawi highlights the role of Arab women especially Arab women writers in fighting oppression and marginality. She explains in The Essential Nawal El Saadawi: A Reader:

It is Arab women alone who can formulate the theory, the ideas, and the modes of struggle needed to liberate themselves from all oppression. It is their efforts alone that can create a new Arab woman, alive with her own originality, capable of choosing what is most genuine and valuable in her cultural tradition, as well as assimilating the progress of science and modern thought. Conscious Arab 
women who no longer live under the illusion that freedom will come as a gift from the heavens, or be bestowed upon them by the chivalry of men, but understand that the road to freedom is long and arduous, and that the price to pay is heavy. Such women alone are those that will lead others [Arab women] to total emancipation. Such Arab women will not hesitate because they know that, if the price to pay for freedom is heavy, the price of slavery is even heavier. (65)

Like El Saadawi, Haddad tries to shatter stereotypical images of Arab women and Arab women writers and the pen is her sword. Haddad writes the novella in English as she is addressing both Western and Arab readers. Her choice of English language is a resistance technique. Haddad is questioning assumptions about female powerlessness in Arab societies, and shows how Arab women writers are involved in changing reality via writing. To Haddad, writing is a resistance weapon. As such, Haddad uses personal testimony and shows the influence of religion, patriarchy, and traditional practices in determining Arab women's status and pinpoints Arab women writers' definite role in changing society. She is asking all Arab women to write to change reality as she believes writing is an act of activism.

To Haddad, writing is a weapon that asserts women's autonomy, and women's role in empowering other women. It is a literary action arising under an overpowering vigorous pressure that interferes with the creative process (Ahmed, A Boarder Passage 61). The reasons the Arab woman writer writes is to expose the ambiguities embedded in the subversion of society's conventional female roles; the need to secure a place in the literary scene, and the obligation to acquire a social role and a writing craft (Mernissi, Scheherazade Goes West 88). Another reason the Arab woman writer writes is her commitment to construct Arab woman's subjectivity. To Arab women writers writing is not only a weapon fighting silencing and oppression, but a means of constructing a new personal, social, and political reality. It is not surprising that the repressive political regimes of the Arab nations deliberately attempt to control the lives of Arab women and especially Arab women writers (Asfour 45, 56). Haddad writes I Killed Scheherazade: Confessions of an Angry Arab Woman to change reality via writing. She writes to ask Arab women writers to shatter norms, secure a social and political role as an Arab woman writer, and give Arab women voice. 
For women to write in the Arab world, it is a revolutionary act even in the twenty-first century. The revolutionary nature of this act lies in its transgression of historically traditional established norms governing gender roles, difficulty of publishing, and the idea of visibility (Ashour and Ghazoul 14; Abouzeid A Biography of Prophet Mohammed 9, Return 91). In establishing their subjectivity, Arab women writers have used writing as a means of personal growth and self -definition. Writing was a challenging experience as Arab women writers fought the established norms by telling their stories to others. This leads to the development of the voice of the Arab women as a subject and enhances their visibility (Abu-Lughod 13). Despite the increase in the number of Arab women writers, only very few of them can devote themselves entirely to the writing process. Family obligations, full-time jobs, or financial pressures are usually the factors that impede them from pursuing the writing career (Abouzeid Return 97).

The burst of literary activity by women in contemporary Arab society is evident. Economic freedom, however, does not necessarily entail intellectual freedom. Arab women who have had the opportunity to embark on a writing career may still encounter opposition to their work, and may even find it impossible to publish, acquire a readership, and face excessive criticism. There has been limited access to literary production for women in spite of the efforts of dedicated critics (Asfour 48, 63, 121). While there is a marked increase in Arab women's participation in public life, and a growing level of awareness on their part, both collective and individual, the process of liberation is not complete. In their struggle for freedom and equality, Arab women writers at times encounter hostility and resistance and at other times solidarity and support (Abouzeid Return 90, 91, 114, Ahmed A Border Passage 97, Haddad 90). They perceive that fighting for their rights will reawaken Arab society in general. Arab women writing journey is a journey of resistance aiming at reform (Haddad 54).

Arab women writers use writing as a weapon to change the course of events. Writing is a weapon that affirms to the Arab woman writer and readers that she is a living being, a person who possesses the power of action and reaction. The reasons the Arab woman writer writes is to expose the ambiguities embedded in the subversion of society's conventional female roles; the need to secure a place in the literary scene and the obligation to acquire a social role and a writing craft. 


\section{Dr. Rasha Abdel Haliem Osman}

Another reason the Arab woman writer writes is her commitment to construct the Arab woman as subject (Ahmed A Quiet revolution 11). It is not surprising that the repressive political regimes of the Arab nations deliberately attempted to control the lives of Arab women and especially Arab women writers. Still, there are challenges that face Arab women writers among which lack of opportunity, censorship whether personal, familial or governmental, economic problems, and lack of time to write (Asfour 55).

Interest in reading Arab women writers increased the number of translated texts as well as the number of texts written in English addressing the Western reader. This interest is fruitful as the complexity and diversity of the Arab world and its literatures can be represented. It is also a guard against stereotyping as Western readers are exposed to a range of styles and ideologies. To Haddad, most Western reviewers of Arab women's books are hostile. They generally write what the Western reader wants and seem to take their cues from the titles and covers. Western reviewers read Arab women's literary productions as sociological and anthropological texts that supposedly reflect the reality of Islam and the Arab world. Most of the times issues of sexuality and oppression take center stage in these reviews. Most reviewers conclude that Arab-Muslim culture is inferior to Western culture regarding the status of women without understanding the cultural and social context of the literary products. As Haddad explains in I Killed Scheherazade: Confessions of an Angry Arab Woman (2010):

Yet before asking: 'what is an Arab woman?' we need to ask another question first: how is a typical Arab woman perceived in the eyes of the non-Arab? Isn't it a perception mainly formed in the Western collective consciousness by a multitude of formulas and generalisations, generated either by a still-persisting Orientalist perspective, or by a post-9/11 hostile view shaped by resentment, fear and condescension? Isn't this woman often seen as a poor helpless female, who is condemned from birth to grave unconditionally to obey the men of the family: father, brother, husband, son, etc? As a powerless soul who doesn't have any control over her destiny? As a defenceless body told when to live, when to die, when to breed, when to hide, when to fade away? As an invisible face masked by layers of fear, vulnerability and ignorance, and utterly cancelled by the Islamic hijab? .... Not only does she exist, but in order to be sincere, and 
scientifically precise, I have regretfully to admit that she is increasingly the ruling model of Arab women nowadays. (27-28)

To Haddad feminist resistance via writing is an ongoing process. While the presence of women on the Arabic literary scene has grown in number and influence in recent decades, there are still fewer women writers than male authors. In addition, Arab women writers do not represent all segments of Arab society. Most Arab women writers come from the middle and upper classes and have had the education and resources needed for intellectual pursuits. This make them represent the lives of middle class women rather than the plight of women from the poorer classes of society (Arenfeldt and Golley 11). Like most Arab women writers, Haddad uses writing as weapon for re-writing Arab women reality. Like many Arab writers she uses every mean to promote women. She even publish her work on the Internet to document Arab women realities and enhance social and political change. As Fereshteh Nouraie- Simone explains in her book On Shifting Ground: Muslim Women in the Global Era (2014):

The rise of global communications is one of the many forces of change that are transforming the lives of Muslim women today-and in turn, being transformed by them. Throughout the Muslim world, women are making their voices heard: documenting the realities of their own lives, exploring their changing identities, and insisting upon greater participation in the public sphere. (17)

In her I Killed Scheherazade: Confessions of an Angry Arab Woman, Haddad challenges the widespread notions of identity, womanhood, and writing techniques. Haddad resists the Arab and Western ideologies concerning Arab women. She even resists the way Arab women react and finds the image they present infuriating. Haddad's active resistance is done via writing a literary autobiographical confession that exhibits her intellectual development and the role of literature on liberating women and reflecting their thoughts and culture. For Haddad, Scheherazade is dead, and the time has come for all Arab women to tell their own stories in their own way to enlighten themselves, empower others and shatter stereotypes. 


\section{Dr. Rasha Abdel Haliem Osman}

Haddad believes that Arab women writers should be concerned about writing their new reality and presenting a different image from the incorrect, stereotyped image prevalent in the West that is nourished by publishers and writers. The international market for Arab women writers is open whether they are writing in Arabic, English or French. At the same time, she aims at creating a new veracity for Arab women. She concludes her I Killed Scheherazade with a moving poem that intertwines all her thoughts about creating a new reality for Arab women writers (156- 157).

Haddad tries to become a spokes woman for Arab women and especially Arab women writers by writing I Killed Scheherazade: Confessions of an Angry Arab Woman, a political pamphlet with the unfolding Arab Spring. Haddad first writes the book in English, then she writes the Arabic version. Haddad tries to speak up for "Arab women" and "Arab women writers" (Haddad 10). I Killed Scheherazade is a literary, poetic attack upon the enemies of feminist expression in the Arab world and a manifesto against Western feminist ideas about Arab women (Haddad 18). Haddad's I Killed Scheherazade also triggers Arab hypocrisy in literary criticism and Christian and Islamic fundamentalism (Haddad 22, 31, 32). Autobiographically weaving her thoughts, Haddad constructs a journal of thought that has the intellectual markings of a manifesto that resists the pressures to marginalize or silence her. To Haddad writing is a liberating tool that enforces change even in the writing norm (80). She states:

Yet, dear Westerner, don't be misled by the fact that you are the obvious addressee of this book: it is not solely addressed to you, but rather, and sometimes even primarily to my fellow Arab citizens. Therefore it is, to a large extent, an effort of self-criticism. And while it will try to reveal the points where hope for today's Arab women lies, it will similarly expose their points of weakness, the challenges they are confronting, and the problems that they are facing/provoking and not dealing with. .... If I unmercifully expose our flaws, it is to better enlighten the undeniable exception that lies within them. (I Killed Scheherazade 2021)

Haddad knows that writing is a form of resistance. To Haddad selfexpression is the heart and soul of all forms of creative writing. In her $I$ Killed Scheherazade, she presents her inner thoughts and feelings and 
shows how she perceives the world and puts it into words. She does not write what the readers or critics want, but writes about the state of Arab women, Arab women writers and her personal truth. Haddad tries to connect with readers, to enlighten them and promote change. As Bell Hooks explains in Talking Back: "For us, true speaking is not solely an expression of creative power, it is an act of resistance, a political gesture that challenges the politics of domination that would render us nameless and voiceless." (19).

Haddad acknowledges how the cultural, economic, political and/or other forces contribute to the bias that women and girls have less value, purpose and voice in the world. Haddad seeks to change and/or defeat these cultural, economic, forces via writing. As a writer, she is not afraid to speak her mind and writes I Killed Scheherazade aspiring change. For Haddad writing is a form of activism that challenges the status quo in the cultural, political, and spiritual realms of the Arab world and the world at large. Haddad denotes:

In the meantime, here's one last glance at my reality OUR reality as Arab women: 'Paradoxically, the more the West comes to terms with the gains of modern feminism, and waxes indignant at the "humiliations" to which Arab women are subjected, the less do women in the Arab world itself open their mouths. (135)

In I Killed Scheherazade, Haddad defies traditional roles and resists structures of oppression. She tries to give voice to women who have long been silenced and devalued and tries to reflect the rich, dynamic life and knowledge of Arab women. Haddad is concerned about reflecting upon social and political change, fighting domination and stereotyping in a straightforward manner. Haddad denotes that she had other thoughts to include in her book, but her decision was concentration on fighting hegemony. She denotes:

There are still so many things that I would have wished to write about in this book: love, solitude, marriages, divorces, age, relationships, the need for space, the need for intimacy, seizing the moment, testing new things, times of ultimate joy times of absolute despair. Also: the persistent harem syndrome, the virginity myth, the art of multi-tasking, the importance of education, the meaning of a career, the value of financial independence. Not to mention: languages, 


\section{Dr. Rasha Abdel Haliem Osman}

ambitions; me raising my kids, my kids raising me; breaking molds, transcending formulas. But I'm not ready for these topics yet. So they'll have to wait. I hope you will, too. (134135)

Haddad uses autobiography as literature. Autobiography is a controversial writing genre that is generally defined as non-fiction. The interest in the genre from the 1960s till the present is ongoing because of the cultural and literary nature of many autobiographical products. As Linda Anderson (2011) explains literature runs in all autobiography as writers add, omit and rewrites personal events (44). Autobiography has many forms among which are self-paintings, sculpture, letters, interviews, blogs, poetry, diaries, journals, and memoirs (Smith and Watson 24). Haddad uses both prose and poetry in writing her autobiographical pamphlet. Using more than one mode of writing is a resistance weapon resisting silencing and hegemony even in the format of writing. Haddad states:

It [I Killed Scheherazade] does not pretend to give answers to the questions posed, nor solutions to the problems exposed nor lessons and formulas to abide by. Its key aspiration is to offer both a testimony and a meditation on what being an Arab woman does and could mean today. Its second aspiration is to achieve the first, away from the dull dryness of rhetorical speech, from the narrow egocentrism of a systematic autobiography and from the escapist allegories of a novel. (20)

Haddad tries to reflect how the roles of Arab women are changing. Their limited roles, notably those of daughters, wives, and mothers are changing. The opportunities for personal development and self-expression have expanded dramatically with the modernization of Arab society. The spread of free compulsory public education, as well as the economic necessity of contributing to the household income, has facilitated Arab women's efforts to join the workforce and increased their participation in public life. The new reality of Arab women's presence in the workplace within the urban environment has created internal and external conflicts. On the personal level, women are torn between the desire to raise a family and the ambition to develop a career (Golley Arab women's Lives Retold 13, Faqir 28). Haddad implies that Arab women writers should write to reveal that the Arab woman is changing both in her role and in her self-perception. Allowed to study, 
work, and travel, the Arab woman has gained more access to power and more control over her life (Haddad 35, 55, 71). Through telling her story, Haddad tells the story of many Arab women. As Fadia Faqir (1998) explains: “.... The I in the narrative is imaginary. To create the self within the medium of language is paradoxically to erase it and place it further in the domain of fiction and transitory representation" (3).

Haddad proves that the image of the Arab woman as silent, passive, and submissive is no longer valid. The contemporary Arab woman is outspoken, active, and assertive. Whatever job she holds, the Arab woman has developed a new image for herself and conspicuous individuality. Haddad explains the traditional role assigned to women still persists in Arab society, but at the same time, old barriers have been shattered and social role expanded (110). The new status of Arab women is varied and complex. Some areas of their lives, notably education and employment, show a marked improvement; others, especially the laws regulating marriage, divorce, child custody, and inheritance, still await reform (Haddad 15, 28, 42). Moreover, certain segments of Arab society, such as peasant, village, and bedouin women, have not benefited equally from the process of modernization, which has mainly affected the urban population. Nevertheless, even in rural and remote areas women's self-awareness has increased (Hannan 92). Significantly, women, especially educated ones who have succeeded in shaping their own futures, serve as role models for other Arab women, and thus serve as instruments of social change. As more Arab women pursue higher education and join the workforce, they inevitably have to grapple with new problems, social, moral, and emotional. The changing profiles of women in Arab society are portrayed in many different ways. Arab women decision to become business women, stay spinsters, participate in wars are being presented via literature.

Haddad believes that Arab women writers should write the new roles of Arab women to foster change. New values emerge as the process of turning public the private as lived by women. Besides, the literature Arab women write focuses on the improvement in the status and lifestyle of Arab women and reflects the rapid social transformation taking place throughout the Arab world (Attar 74). To Haddad, literature written by Arab women writers should depict how Arab women have made great strides in freeing themselves from the bondage of illiteracy and seclusion, and have entered more productively into national life (Badran Gender and Islam). While the liberation of women has not yet 


\section{Dr. Rasha Abdel Haliem Osman}

been fully attained, and many issues remain unresolved, major advances are clearly evident (El Tahwy 205). Haddad explains:

Arab woman is no myth; the 'other atypical, rebellious, independent, modern, free thinking, unconventional, highly educated, self-sufficient Arab woman exists as well. Moreover, she is not as uncommon as you might suppose. And there lies the key to this testimony, which is nothing but a small link in a long chain of works and essays already written about this topic. Its aim lies not in proving that the prevalent image of the typical Arab woman is all wrong. But in showing that it is incomplete. And in placing next to it the 'other' image, so that the latter becomes an intrinsic part of the West's (and of the Arab world's) common perception of Arab women in general.

Yes, the 'other' Arab woman most certainly exists. She needs to be noticed. She deserves to be acknowledged. And I am here to tell her story, or at least one of her many stories: mine. (I Killed Scheherazade 31-32)

Haddad writes I Killed Scheherazade to foster her existence and fight all types of hegemony. The autobiographical account is an internal monologue written in the face of tyrannical life forces. Haddad tries to document Arab women writers and Arab women lives with an incredible mix of the public and factual, the personal and the intimate. As Fadia Faqir(1998) states: "[Arab women writers] write their texts [autobiographical accounts] to negotiate a textual, sexual, linguistic space for themselves within a culture which is predominately maledominated." (6) Haddad believes that all forces in the Arab World play against Arab women. She is a voice for so many Arab women who have been robbed of their voices. She also vigorously fights the incorrect picture of Arab women as traditional, uneducated, and humiliated. Haddad writes as a form of social and cultural resistance. Haddad rewrites Arab women's "history" and tells "her-story" or the "other" side of the story (Smith and Watson 70).

To Haddad, Arab women writers are concerned about reflecting the winds of change that are blowing across the Arab world. Even during the most difficult times, Arab women writers are intensely involved in the social and political concerns of their countries and societies (Faqir 7). They are not living on the peripherals of social and 
political events. Their views on important issues are sometimes different from those of men. This could be one reason why their creativity is looked down upon, and that their contributions do not achieve the effect they are looking for. Arab women writers' views reflect a genuine concern for their people and their country (Haddad 75, 91). To Haddad, the role of Arab women writers is needed more than ever because of the social and political changes that characterize the era namely the Arab Spring (Interview). In other words, Arab women writers should get more involved in the cultural, civil and human rights' movements that advocate an improvement in the legal and social conditions of men and women (Haddad 29). Haddad understands that Arab women writers' social commitment is recognized both inside and outside their countries as they are leaders of change (LadKani 1). To Haddad, Arab women writers bring change via telling their stories, and nourishing both the hearts and minds of readers. What increases Arab women responsibility is their visibility worldwide (I Killed Scheherazade 95).

Another reason Haddad writes I Killed Scheherazade is resisting censorship. Haddad is highly concerned about fighting censorship. She discusses censorship and how it hinders Arab women writers. To Haddad, censorship is a challenge that affects the literary production of the Arab woman writer. Many Arab writers face censorship and confiscation even in the 21th century. Throughout Arab women writing history censorship hindered women writers. Some literary products were censored and confiscated because of political repression like the products of women prisoners. Political censorship and self-censorship are not exclusive to women authors in the Arab world; the former affected the work written by men as well (Faqir 10-11).

Nawal al-Saadawi published her first work of nonfiction, Women and Sex, in Beirut in 1972 as she was not permitted to publish the book in Egypt. She was also arrested in the year 1999 for her alleged transgressive writings and talks. Al- Saadawi's Women and Sex deals candidly with taboos surrounding female sexuality, including virginity, circumcision, and crimes of honor. It caused such uproar that she was dismissed from her post as Egypt's director-general of health education. As with other provocative works that she has penned, the book has been banned in several Arab countries. In Lebanon, Layla Ba'labakki's collection of short stories, A Spaceship of Tenderness to the Moon (1963) led to her trial on charges of obscenity and endangering public morality. Although she was eventually acquitted, she stopped publishing 


\section{Dr. Rasha Abdel Haliem Osman}

works of fiction since then. Suhayr al-Tall of Jordan went through a traumatic experience following the publication of her story "The Gallows" in Amman in 1987. The same was the case of the writer Burned Alive (1998). Zabya Khamis of the United Arab Emirates was arrested and jailed for five months without trial as punishment for writing allegedly transgressive poetry. In Saudi Arabia, women writers have used writing as a resistance weapon. Saudi women writers write to fight patriarchy, represent the female identity and reject stereotypical pictures. Still, some of their writings are rejected, criticized for themes and writing techniques, and sometimes confiscated as in the case of Rajaa al-Sanea and Eman al-Nafjan (Alsayegh 7)

Censorship does not hinder Arab women writers from expressing their views, finding their voice and forging their identities. During the 1990s Arab countries were subjected to cruel, oppressive regimes. In the face of such overwhelming political, economic, social, and cultural repression, women writers openly fought against their countries' dictatorships, challenged the dominant, traditional norms of women's sexual behavior in their respective patriarchal societies, and managed to publish quite revolutionary literary products. The women writers of this generation (the generation of 1990s) embarked on a search for a voice that would participate in history by reporting the harsh reality of the dictatorship. To avoid generalizations, both men and women unsurprisingly adopted different methods to achieve their goals, and it is precisely this tendency to assume distinct methods what namely identifies the distinguishing quality between literature written by women and that written by men. Radwa Ashour and Ferial Ghazoul maintain that writing for women is an act of rebelliousness, and a form of resistance that attempts to influence the establishment of democracy in the Arab world (3). Ashour and Ghazoul's comment particularly defines the political scene of the last two decades of the twentieth century, the 2000s era and the post Arab Spring period during which Arab countries are trying to fight dictatorship, or move through the transition from dictatorship to democracy. Like Ashour, Mona El Tahawy (2016) maintains that writing is an act of resistance for women, an act of survival that attempts to change the social and political state in the Arab world (211).

It is interesting to note that the ever watchful eye of the censor does not prevent Arab women writers from expressing their thoughts, but rather affects the clarity and simplicity of their literary works. In fact, the need to escape the censor and still make sure that their voices 
are heard stimulates them to explore new forms of expression and presentation. Haddad decides to use more than one format in writing $I$ Killed Scheherazade. She merges prose, poetry, essay, fiction and nonfiction to enforce the idea of rebelliousness against the censor view of using definite technicalities in writing art. Haddad draws the readers' attention that besides problems of censorship, Arab women writers may also encounter opposition to their work within their own families. This was the case of Alifa Rifaat, Nawal al-Saadawi, and Leila Abouzeid. As Brinda J. Mehta (2014) explains Arab women writers continue to express themselves and achieve respect and recognition whatever the hindrances they face in their career (9).

Haddad is encouraging Arab women writers to write what they think and feel. To her, writing is an enlightening act to both the writer and the reader. Haddad believes that writing dissects culture and society and offers insight into how writers think. Arab women should deal with all topics whether personal, social or political. They can use whatever creative approach, technique, or point of view. They should be lively, outspoken and proactive if they really aspire to be heard and change the Arab world to the better. Arab women writers should fight forces and personal censorship. Haddad states:

To be a woman writer in an Arab country means, of course, suffering cultural 'blackouts' and underestimation, and being marginalised, whether innocently or systematically, by men or by women, or by both together. To be a woman writer in an Arab country means to need to be rather cunning and slippery, to show a bit here and to mask a bit there. To be a woman writer in an Arab country means, for many - but not for all, fortunately - to write things in code, so that, for example, a lover becomes a 'good friend and a rapist father would be the father of "the poor girl next door. ... To be a woman writer in an Arab country means to impose strict self-censorship, a thousand times harsher than any official censorship imposed from the outside. To be a woman writer in an Arab country means to plan (71-72)

Hadded is concerned with censorship. She aims at reform and asks women writers to continue writing. For her self-expression is a weapon of change and reform. To Haddad, censorship should be concerned about the way themes are presented, writing techniques, and helping the 
writers improve their craft. If censors want their countries to improve they should open the door for all themes and cherish experimenting techniques. She states:

For what can censorship really hope to achieve, when banning a book guarantees it notoriety and widespread success? Why impose censorship in an age when, at the press of a button, we can get all the information we need and more? Censorship should be underhand and sly, but it is stupid beyond belief in our Arab world. Censorship should be advanced, but it is primitive beyond belief in our Arab world. Official Arab cultural institutions claim that censorship protects cultural values, but it only protects narrow cultures: the cultures of deceit, backward thinking and the Dark Ages. (86)

Haddad believes that enhancing literary criticism will demolish the hazards of censorship and enhance women writing and eventually women status. Haddad understands that Arab critics writing about women, particularly those situated in the Arab world, are viewed in the Arab literary circles with suspicion. If they do not write about Arab women writers, they are chastised for ignoring them. If they do, they are accused of attempting to marginalize them. Worse, if critical, literary critics are branded as hostile to women and their cause. While this judgment may be true of some, it should not be used, as it is often used as a blanket statement to dismiss Arab critics as a whole. Still, the way Arab women writers write is affected by censorship. Haddad asks women writers to write the personal and forget about censorship. Haddad explains the difficult mission of Arab women writers:

It's not easy to be a woman who writes without compromise in an Arab country. It's not easy to take your clothes off, layer by layer, in front of strangers. It's not easy to expose others to your ideas, your life, your visions, your dreams, your fears, your inspirations, your mistakes, your failures and your confessions, when these others are not just readers, but ruthless 'judges' of you as a person. It's not easy to face up to the monster of prejudice and embarrassment, and to prove, despite that intimidating monster, your ability to express your ultimate self: yourself in its strength as well as its weakness, in its disappointments and its hopes, in its beauty and its ugliness, in its heights and its depths, in its 
glittering nobility and its baseness.

No, it's definitely not easy to be a woman who writes without compromise in an Arab country. People know that very well. (73)

Haddad believes that Arab women writers should write about all themes even cultural dilemma. Arabs are facing a recurrent dilemma namely following Traditional dogma or Western ideology. The dilemma is never resolved though the topic is frequently discussed. Arab women writers present this topic in their literary products. Haddad is concerned about reform and reform entails self-confrontation of all the social, political, and cultural problems. She states:

Yes, I killed Scheherazade. I killed her in me. And I am quite determined to kill everything and everyone that even remotely looks or behaves like her in my unconscious, imagination and mind. So her sisters, daughters, granddaughters and all her descendants had better close down the concessions' business, or stay away, far away from me.

For there's an angry Arab woman out there. She's got her own 'not-intended-for-negotiation' stories, her own notgranted-by-anybody' freedom and life, and the perfect murder weapon. And there's no stopping her now. (146-147)

To Haddad, Arab women writers should explore sexuality widely. They should denounce the strict practices surrounding female sexuality: veiling, seclusion, social segregation, virginity, circumcision, crimes of honor, and premarital sex. At the same time, they should offer a rare glimpse into intimate relations between men and women, which reveal that the sexual code is often violated in everyday life (99). Haddad knows that despite the sexual repression that predominates in traditional Arab society, the themes of love, passion, and erotic pleasure have always been celebrated in Arabic poetry, both classical and modern. Haddad understands Arab women writers began to write openly about their sexuality in the late 1990s onward. Haddad advocates being more open concerning writing the body $(110,111,118)$.

Haddad advocates focusing on different phases in a woman's life: adolescence, adulthood, middle age, child bearing and child rearing. In short, writing all woman's life phases. Haddad believes that Arab 


\section{Dr. Rasha Abdel Haliem Osman}

women's literary productions should paint a vivid portrait of female sexuality over a complete life cycle. They should even portray lesbianism, a controversial topic in the Arab world ${ }^{4}$. Haddad knows that despite censorship and the risk of ostracism, sexuality has been explored by many Arab women writers. This is evident in Nura Amin's "My Mother's Friend" and Alifa Rifaat in her story "My World of the Unknown". The issues of virginity and crimes of honor are raised. The sharp contrast between the sexual mores of the East and those of the West are also explored. The patriarchal values of Arab society, which underlie the moral and sexual codes, are presented. Haddad wants Arab women to be more open in reflecting their sexuality. To Haddad writing about the body is a form of resistance. She states:

Life, to me, is a physiological, physical, instinctual, sensory experience, in as much as it is also an emotional, psychological and intellectual one. And so is writing. To me, everything is palpable, and can be touched: words, thoughts, feelings, the unconscious, imagination, love, etc. If I write about the body and sex, about my desires and needs, I don't do that to titillate readers, as the machismo of some Arab critics accuses me of doing, but in order to be true to what I live inside, and what preoccupies me (84).

Haddad believes that writing the body will serve a forum on how an Arab woman writer views herself and how society imposes a certain image on her. Writing the body will offer opportunity for the readers to look inside the minds of women writers and view their struggles to forge a connection between mind and body. Arab women writers should not censor themselves from writing the body as writing the body will not liberate women writers but will give the reader a greater understanding of Arab women and Arab culture. Haddad states:

I do not separate the subject matter of my life from the (subject matter of my writing: any experience that I live is a potential text (written, or yet to be written), and everything that I write is a potential life experience (lived, or yet to be lived). When I write, I feel like I am writing with my body and on my body, with my nails and from them, and that the words are erupting from my pores and being inscribed on my skin. It's a brutal, violent and bloody hunting trip, as much as it is a sensitive, contemplative journey. This is also how I read, and love: words and feelings echo in my flesh as hard 
as they do in my conscious and unconscious mind. In my daily life, my intimate spirit does not separate (I Killed Scheherazade 67)

Haddad uses traditional, innovative and experimental approaches. Her mode of writing is affected by her vision and attitude. She writes $I$ Killed Scheherazade in English and eventually translates the book in Arabic. Haddad blends both prose and poetry. Haddad does so to write her thoughts and resist conformity. The autobiographical novella is a collection of chapters, each leading off the previous one and touching on topics related to resistance in writing. She explains: "I want to try facing that dragon. As a writer. As a woman. As a human being. With the tools of the writer. With the tools of the woman. Not conforming to one mode of writing is a form of resistance" (23).

Haddad resists via writing and experimenting different modes. She tries to show how contemporary Arab women and specifically Arab women writers from across the Arab world have multiple voices and rich lives. Haddad reflects the Arab woman writer experience in an autobiographical literary account. She speaks of writing as a tool of resistance and change. Haddad shatters traditional norms and bequeathed customs. Via writing she takes a rebellious, liberal stand. Haddad's narrative opens windows onto Arab culture and society and offers keen insights into what Arab women specifically Arab women writers really are, fight sexism, and resists hegemony in all its forms. Even her techniques of writing are revolutionary as she uses both prose and poetry. 


\section{Dr. Rasha Abdel Haliem Osman}

\section{Works Cited}

Abouzeid, Lelia. A Biography of Prophet Mohammed: Life of the Prophet Mohammed. Beirut: Dar Al-Kotob Al-Ilmiyah, 2009.

---. Ruju 'Ila Tufula [Return to Childhood]. 10th ed. Casablanca: Al Madariss, 2008.

---. Return to Childhood: The Memoir of a Modern Moroccan Woman. 2nd ed. The author and Heather Logan Taylor. Austin, TX: Center for Middle Eastern Studies at the U of Texas at Austin, 1999.

Abu-Lughod, Lila, ed. Remaking Women: Feminism and Modernity in the Middle East. Princeton: Princeton U P, 1998.

Ahmed, Leila. A Border Passage: From Cairo to America- A Woman's Journey. New York: Penguin, 2000.

---. A Quiet Revolution: The Veil's Resurgence from the Middle East to America. New Haven: Yale U P, 2011.

Alsayegh, Wijdan. Veil and Lipstick: Three Modern Arab Women Writers. New York: Alsayegh and Zimmerman Publication, 2018.

Amireh, Amal and Lisa Suhair Majaj, Intro. "Going Global: The Transnational Reception of Third World Women Writers." Feminist Literary Theory: A Reader. Ed. Mary Eagleton. Oxford, London: Blackwell, 2011, 417-419.

Anderson, Linda. Autobiography. $2^{\text {nd }}$ ed. New York: Routledge, 2011.

Arenfeldt, Permille and Nawar Al-Hassan Golley, Eds. Mapping Arab Women's Movements: A Century of Transformation from Within. Cairo: The AUC P, 2012.

Asfour, Gaber. Defā'an àn Al Mar'aa (In Defense of Women). Cairo: Al Hāyaa Al Māsriyaa Al-'Amma Lil Al Kātab, 2007.

Ashour, Radwa and Ferial Ghazoul. Arab Women Writers: A Critical Reference Guide, 1873-1999. Cairo: The AUC P, 2008.

Attar, Dena. "The Portable Cage: Women and Fundamentalism." The Trouble and Strife Reader. Eds. Deborah Cameron and Joan Scanlon. New York: Bloomsbury Academic, 2010, 56-78.

---. Gender and Islam in Africa: Rights, Sexuality, and Law. Austin, TX: U of Texas P, 2011.

El Guindi, Fadwa. Veil: Modesty, Privacy and Resistance. New York: Berg, 2003.

El Saadawi, Nawal. The Essential Nawal El Saadawi: A Reader. London: Zed Books, 2013.

---. The Hidden Face of Eve, Women in the Arab World. Trans. and ed. Sherif Hetata, London: Zed P, 2015.

El Tahawy, Mona. Headscarves and Hymens: Why the Middle East Needs a Sexual Revolution. New York: Farrar, Straus and Giroux, 2016.

Faqir, Fadia. In the House of Silence: Autobiographical Essays by Arab Women Writers. New York: Garnet Publishing, 1998. 
Felski, Rita. "Doing Time: Feminist Theory and Postmodern Culture." Feminist Literary Theory: A Reader. Ed. Mary Eagleton. Oxford, London: Blackwell, 2011, 37-41.

Golley, Nawar Al-Hassan. Arab Women's Lives Retold: Exploring Identity through Writing. New York: Syracuse UP, 2007.

---. Reading Arab Women's Autobiographies: Shahrazad Tells Her Story. Texas: U of Texas P, 2003.

Haddad, Joumana. I Killed Scheherazade: Confessions of an Angry Arab Woman. Chicago: Chicago Review P; 2011.

Hannan, June. Feminism. $2^{\text {nd }}$ ed. London: Pearson, 2011.

hooks, bell. Talking Back: Thinking Feminist, Thinking Black. ${ }^{\text {nd }}$ Edition. Between the Lines, 1999.

Ladkani, Ghida. "7 Lebanese authors you should be reading." StepFeed, 25 December 2015, https://stepfeed.com/7-lebanese- authors you-should be reading. Accessed 2 January 2018.

Mehta, Brinda J.. Dissident Writing of Arab Women. New York: Routledge, 2014.

Mernissi, Fatema. Scheherazade Goes West: Different Cultures, Different Harems. NY: Washington Square P, 2001.

Mohanty, Chandra Talpade. "'Under Western Eyes: Feminist Scholarship and the Colonial Discourses' Third World Women and the Politics of Feminism." Feminist Literary Theory: A Reader. Ed. Mary Eagleton. Oxford, London: Blackwell, 2011, 399-402.

Nouraie-Simone, Fereshtech. On Shifting Ground: Muslim Women in the Global Era. Feminist Press, 2014.

Sadiqi, Fatima. "Feminization of Public Space: Women's Activism, the Family Law and Social Change in Morocco." Journal of Middle East Women's Studies 2.2 (2006): 1-37.

Smith, Sidonie Anne and Watson, Julia Anne. Life Writing in the Long Run: A Smith and Watson Autobiography Studies Reader. Michigan: Michigan Publishing Services, 2016.

Wilson-Goldie, Kaelen. "Joumana Haddad: A Writer Who Loves to be hated". The National, 27 November 2010, https://www.thenational.ae/arts-culture/books/joumana-haddad-awriter-who-loves-to-be-hated-1.505792 Accessed 21 January 2018.

Zoellner, Tom. "Doomed to Survive, but Not Live: An Interview with Joumana Haddad." Los Angeles Review of Books, 11 February 2019, https://lareviewofbooks.org/article/doomed-to-survive-but-not-livean-interview-with-joumana-haddad Accessed 22 February 2019. 